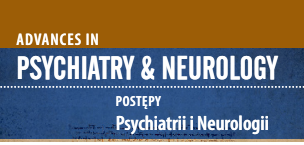

Correspondence to/

Adres do korespondencji:

Mariusz Głuszak

Oddział Neurologii i Udarowy

SP ZOZ w Leżajsku

ul. Narutowicza 3C/25

37-450 Stalowa Wola

tel.: +48667770806

e-mail: Mariusz-gluszak@wp.pl

Submitted/Otrzymano: 01.11.2017

Accepted/Przyjęto do druku: 04.12.2017

\section{NON-PARANEOPLASTIC VARIANT OF LIMBIC ENCEPHALITIS - CASE REPORT}

\section{NIEPARANOWOTWOROWY WARIANT LIMBICZNEGO ZAPALENIA MÓZGU - OPIS PRZYPADKU}

\author{
Mariusz Głuszak', Małgorzała Pazderska-Głuszak², \\ Agata Gut-Lepiech ${ }^{3}$, Aleksandra Wierzbicka ${ }^{4}$, \\ Tomasz Litwin' ${ }^{5}$ I Iwona Kurkowska-Jastrzębska ${ }^{5}$
}

\author{
'Neurology Ward, Independent Public Healthcare Centre, Leżajsk, Poland \\ Individual Medical Practice, Poland \\ ${ }^{3}$ Department of Neurology, Clinical and Provincial Hospital No. 1, Rzeszów, Poland \\ ${ }^{4}$ Department of Clinical Neurophysiology, Institute of Psychiatry and Neurology, \\ Warsaw, Poland \\ 5ll Department of Neurology, Institute of Psychiatry and Neurology, Warsaw, \\ Poland \\ 'Oddział Neurologii i Udarowy, SP ZOZ, Leżajsk, Polska \\ 2Indywidualna Praktyka Lekarska, Polska \\ ${ }^{3}$ Klinika Neurologii, KSW nr 1, Rzeszów, Polska \\ ${ }^{4} Z a k ł a d$ Neurofizjologii Klinicznej, Instytut Psychiatrii i Neurologii, Warszawa, Polska \\ 5II Klinika Neurologii, Instytut Psychiatrii i Neurologii, Warszawa, Polska
}

\begin{abstract}
Purpose: Limbic encephalitis (LE) is a rare but necessary condition to consider when experiencing cognitive disorders, seizures, and psychiatric disorders.

Case description: This article presents a case of a 28-year-old patient with uncontrolled disease history, with systemic symptoms of viral infection and prolonged convulsive seizure status. Based on clinical symptoms, magnetic resonance imaging of the brain and cerebrospinal fluid test results revealed LE. After treatment and rehabilitation, the patient returned to work.

Comment: Limbic encephalitis was first described in 1960. In terms of aetiology, we divide LE into non-infectious (a para nitrogen syndrome primarily associated with small cell lung cancer) and infectious cases (caused by herpes simplex virus). Other cases of autoimmune diseases have also been reported - non-paraneoplastic limbic encephalitis (NPLE), in which the presence of antibodies against the antigen of the neuronal membrane is observed. Non-paraneoplastic LE variants are examples of potentially reversible LE variants.
\end{abstract}

Key words: limbic encephalitis, paraneoplastic syndrome, onconeuronal antibodies.

\title{
Streszczenie
}

Cel: Limbiczne zapalenie mózgu (LE) jest chorobą rzadką, którą należy jednak uwzględnić w przypadku wystąpienia u pacjenta zaburzeń poznawczych, napadów padaczkowych i zaburzeń psychicznych.

Opis przypadku: W pracy przedstawiono przypadek 28-letniej pacjentki z nieobciążonym wywiadem chorobowym, u której wystąpiły objawy ogólnoustrojowe infekcji wirusowej oraz przedłużający się drgawkowy stan padaczkowy. Na podstawie objawów klinicznych, obrazu rezonansu magnetycznego mózgu i wyników badań płynu mózgowo-rdzeniowego rozpoznano LE. Po leczeniu i rehabilitacji pacjentka wróciła do poprzednio wykonywanej pracy.

Komentarz: Limbiczne zapalenie mózgu zostało opisane po raz pierwszy w 1960 r. Pod względem etiologicznym wyróżniamy przypadki nieinfekcyjne LE (o charakterze zespołu paranowotworowego związanego głównie z rakiem drobnokomórkowym płuc) oraz przypadki infekcyjne LE (spowodowane przez wirusa opryszczki pospolitej). Opisano również przypadki związane z chorobami 
autoimmunologicznymi - nieparanowotworowe warianty LE, w których niekiedy obserwuje się obecność przeciwciał skierowanych przeciwko antygenom błony komórek nerwowych. Nieparanowotworowe warianty LE są przykładem potencjalnie odwracalnych wariantów LE.

Słowa kluczowe: limbiczne zapalenie mózgu, zespół paranowotworowy, przeciwciała anty-NMDAR.

\section{PURPOSE}

Limbic encephalitis (limbic encephalitis - LE) is a rare but necessary condition to consider when experiencing cognitive disorders, seizures, and psychiatric disorders. The disease usually develops within a few days or weeks and has different clinical picture, depending on what symptoms are most frequent.

\section{CASE DESCRIPTION}

On 19 December 2007, a 28-year-old patient, an office worker, with no medical family history, who did not take any drugs or abuse substances, developed systemic symptoms of a viral infection (fever up to $39^{\circ} \mathrm{C}$, joint aches and muscle weakness). On the $4^{\text {th }}$ day of the disease, she had her first generalized tonic-clonic seizure. The patient was admitted to the Neurological Ward of District Hospital, where after a few hours she regained her consciousness (she was able to walk with her husband's help). The diagnosis of symptomatic seizure was performed; laboratory tests (except for slight increase in C-reactive protein [CRP]) and general analysis of cerebrospinal fluid showed no irregularities. The brain scan showed no damage to brain structures (Figure IA). In the afternoon the same day, secondarily generalized, focal seizure episodes occurred and the patient was transferred to intensive care unit (ICU) where she was put into a thiopentone barbiturate-induced coma. The patient was awakened after 36 hours, diluted; she was given a valproic acid with sodium valproate (2 x $500 \mathrm{mg}$ ) and oxcarbazepine (2 x $300 \mathrm{mg}$ ). Despite the treatment, frequent motor focal seizures and disturbances of consciousness continued to occur. Magnetic resonance imaging (MRI) and angiography showed no abnormalities. Due to the growing number of seizures, thiopental was re-administered, but the seizures were not sufficiently controlled. During the whole stay in the ICU, the patient run fever up to $38-39^{\circ} \mathrm{C}$ (chest $\mathrm{X}$-ray, blood and urine tests, and secretions from the airway did not show inflammatory changes). Fourteen days after onset of the disease, an itchy rash appeared on the right half of the face in the ear area, cheek and corner of the mouth. As viral encephalitis was suspected, the patient was administered acyclovir (500 mg three times per day, intravenously). Control computed tomography (CT) revealed
CEL

Limbiczne zapalenie mózgu (limbic encephalitis - LE) jest chorobą rzadką, którą należy jednak uwzględnić w przypadku wystąpienia u pacjenta zaburzeń poznawczych, napadów padaczkowych oraz zaburzeń psychicznych. Choroba rozwija się zazwyczaj w ciągu kilku dni lub tygodni i ma różny obraz kliniczny, w zależności od objawów dominujących.

\section{OPIS PRZYPADKU}

U 28-letniej pacjentki z nieobciążonym wywiadem chorobowym, nieprzyjmującej leków na stałe, negującej stosowanie używek, będącej pracownikiem biurowym 19 grudnia 2007 r. pojawiły się objawy ogólnoustrojowe infekcji wirusowej (stany gorączkowe do $39^{\circ} \mathrm{C}$, bóle mięśni i stawów). W 4. dobie zachorowania wystąpił pierwszy w życiu uogólniony napad padaczkowy toniczno-kloniczny. Pacjentka została przyjęta na Oddział Neurologiczny szpitala powiatowego, gdzie po kilku godzinach odzyskała przytomność (przy asekuracji męża mogła chodzić). Wykonano diagnostykę padaczki objawowej - badania laboratoryjne (z wyjątkiem niewielkiego wzrostu stężenia białka C-reaktywnego) i badanie ogólne płynu mózgowo-rdzeniowego były prawidłowe. W tomografii komputerowej (CT) mózgu uwidoczniono prawidłowy obraz struktur mózgu (ryc. IA). W godzinach popołudniowych tego samego dnia wystąpiły napady ogniskowe wtórnie uogólniające się i pacjentkę przeniesiono na Oddział Intensywnej Opieki Medycznej (OIOM), gdzie została wprowadzona $\mathrm{w}$ śpiączkę tiopentalową. Pacjentkę wybudzono po 36 godzinach, rozintubowano, włączono preparat kwasu walproinowego $\mathrm{z}$ walproinianem sodu (2 x $500 \mathrm{mg}$ ) i okskarbazepinę (2 x $300 \mathrm{mg}$ ). Mimo leczenia nadal występowały częste napady ogniskowe ruchowe $\mathrm{z}$ zaburzeniami świadomości. W wykonanych badaniach rezonansu magnetycznego (MRI) mózgu i angio-MRI nie stwierdzono nieprawidłowości. Ze względu na nasilenie liczby napadów ponownie włączono tiopental, niestety nie uzyskano dostatecznej kontroli napadów padaczkowych. Przez cały pobyt na OIOM-ie pacjentka gorączkowała do $38-39^{\circ} \mathrm{C}$ (RTG klatki piersiowej, posiewy krwi, moczu, wydzieliny $\mathrm{z}$ dróg oddechowych nie wykazywały zmian zapalnych). W 14. dobie choroby na prawej połowie twarzy w okolicy mał- 
hypodense areas within the medial temporal lobes (suspected herpes simplex virus-induced inflammatory lesions), as shown in Figure IB. Due to intractable convulsive status epilepticus in the course of encephalitis, probably caused by herpes simplex virus, the patient was transferred to II Department of Neurology at the Institute of Psychiatry and Neurology in Warsaw. Right after admission, the patient's condition was serious, she was unconscious, but reacted to pain, and Babinski's reflex occurred on both sides of the body. There were healing wounds on the skin of the right cheek and ear. The patient kept receiving continuous thiopental infusion, but despite its administration, she continued to have generalized seizures. It was decided that the patient would come off thiopental, and $1000 \mathrm{mg}$ of phenytoin was administered intravenously (then 1 pill orally by probe, three times per day). Lumbar puncture was performed: glucose - $85 \mathrm{mg} \%$, protein - $30 \mathrm{mg} \%$, cytosine - 5 (residue: granulocytes - $20 \%$, lymphocytes - $38 \%$, monocytes - $42 \%$ ), negative oligoclonal bands, index -0.484 , daily synthesis - 0. Magnetic resonance imaging of the brain revealed bilaterally increased signal intensity on T2 and FLAIR images in the hippocampus (no enhancement after contrast injection), and thus LE was diagnosed (Figure IIA).

Video EEG recordings captured recurrent clinical seizures beginning with paroxysmal activity in left temporal lobe, then moving to the right hemisphere of the brain, and ending with a generalization and postictal symptoms of primary paroxysmal attack lasting 3-4 minutes with spasms of the jaw and lips. As phenytoin turned to be ineffective, topiramate was administered (orally) in żowiny usznej oraz policzka i kącika ust pojawiła się swędząca wysypka. Podejrzewając u chorej zapalenie wirusowe mózgu, włączono acyklowir (500 mg x 3 i.v.). Wykonane kontrolne CT uwidoczniło hipodensyjne obszary w obrębie przyśrodkowych części płatów skroniowych (podejrzenie zmian zapalnych w przebiegu opryszczki) widoczne na rycinie $1 \mathrm{~B}$. Ze względu na oporny na leczenie drgawkowy stan padaczkowy w przebiegu zapalenia mózgu, prawdopodobnie o etiologii opryszczkowej, pacjentka została przeniesiona do II Kliniki Neurologicznej Instytutu Psychiatrii i Neurologii w Warszawie. Przy przyjęciu pacjentka była w stanie ciężkim, nieprzytomna, ale z zachowaną reakcją na ból, z obecnym obustronnie objawem Babińskiego. Na skórze prawego policzka i małżowinie usznej były obecne gojące się rany. Pacjentka otrzymywała ciągły wlew z tiopentalu, mimo którego utrzymywał się stan padaczkowy napadów ogniskowych uogólniających się. Rozpoczęto odstawianie tiopentalu, podano dożylnie fenytoinę $1000 \mathrm{mg}$ (następnie doustnie 3 x 1 tabletka przez sondę). Wykonano nakłucie lędźwiowe: glukoza - $85 \mathrm{mg} \%$, białko $30 \mathrm{mg} \%$, cytoza - 5 (osad: granulocyty - 20\%, limfocyty - 38\%, monocyty 42\%), prążki oligoklonalne ujemne, indeks - 0,484, synteza dobowa IgG - 0. W MRI mózgu uwidoczniono obustronnie podwyższony sygnał w T2 i FLAIR (fluid-attenuated inversion recovery) w obrębie hipokampów (bez wzmocnienia po kontraście) - rozpoznano LE (ryc. IIA).

W badaniu wideo-EEG zarejestrowano powtarzające się napady kliniczne rozpoczynające się czynnością napadową w lewej okolicy skroniowej, przechodzącą następnie do prawej półkuli mózgu, kończącą się uogólnieniem i zwolnieniem ponapadowym czynności podstawowej, trwającą 3-4 minuty, z towarzyszącymi drgawkami żu-
A

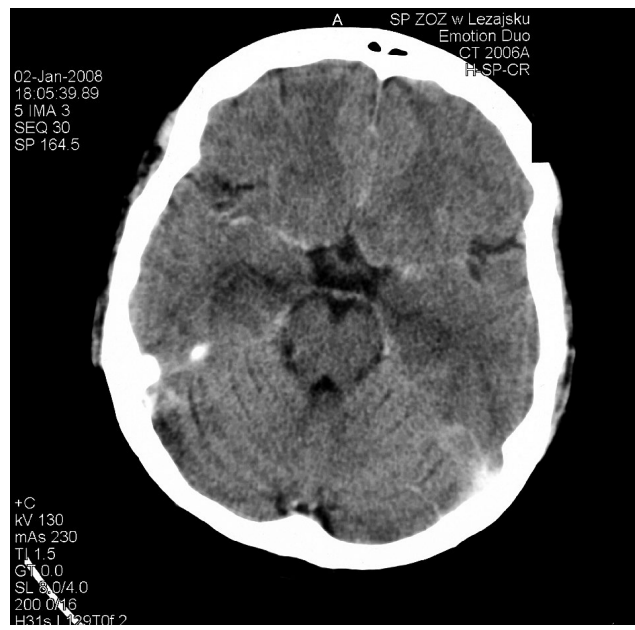

B

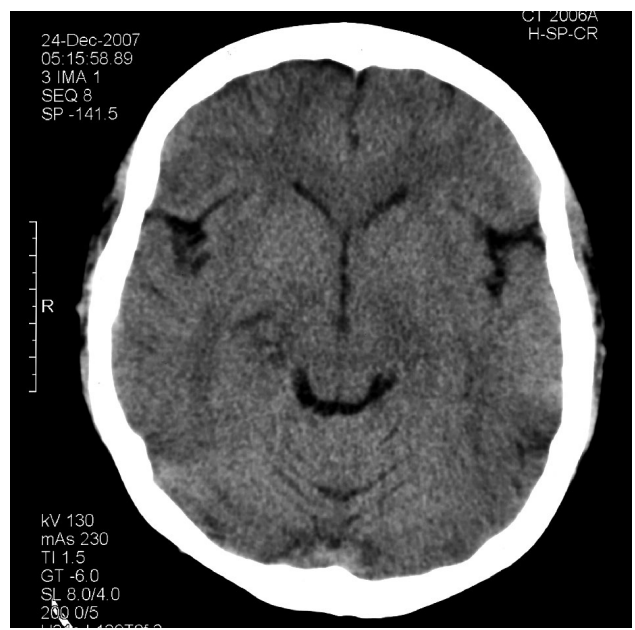

Figure I. Computed tomography head scan performed the first day and nine days after the symptoms occurred with visible hypodense changes in both medial temporal lobes (B) compared with normal first test (A)

Rycina I. Badanie tomografii komputerowej głowy pacjentki wykonane w pierwszej dobie i 9 dni od początku objawów z widocznymi hipodensyjnymi zmianami w obu przyśrodkowych płatach skroniowych (B) w porównaniu z prawidłowym badaniem pierwszorazowym (A) 
A

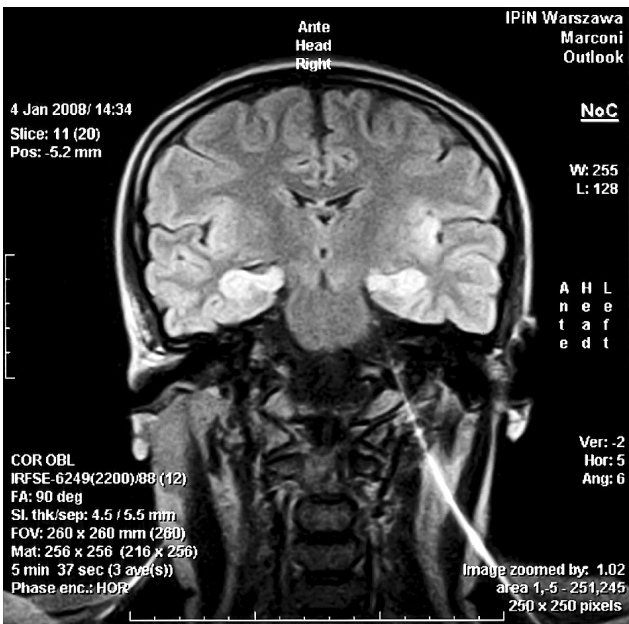

B

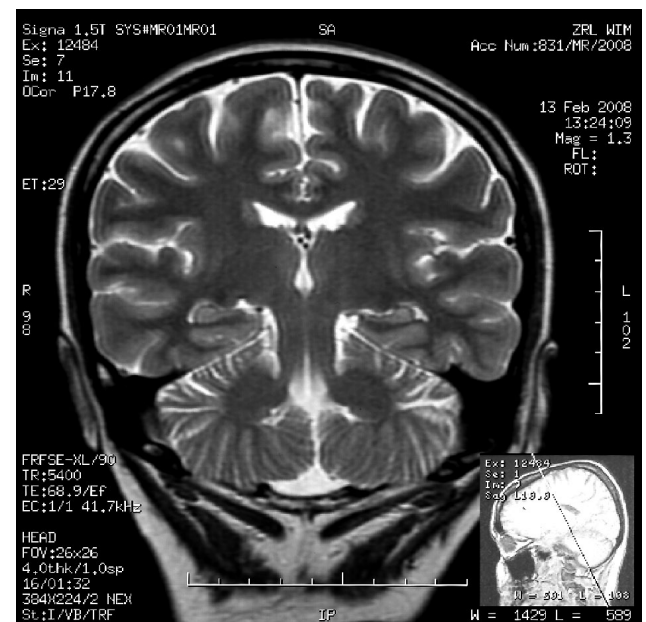

Figure II. Magnetic resonance image of the patient's brain. A) Hyperintensive changes visible on FLAIR and T2 images in both medial temporal lobes and hippocampus (acute phase of disease). B) Normal image performed 2 months later Rycina II. Obraz rezonansu magnetycznego mózgu pacjentki. A) Widoczne w FLAIR i T2 obustronne hiperintensywne zmiany w obu przyśrodkowych częściach płatów skroniowych i hipokampów (ostra faza zachorowania). B) Obraz prawidłowy wykonany 2 miesiące później

increasing doses in successive days up to 2 x $500 \mathrm{mg}$. After further EEG recording (Figure III), carbamazepine was added to the pharmacotherapy $(2 \times 100 \mathrm{mg}$ to be increased up to $600 \mathrm{mg}$ per day).

During hospitalization, the patient experienced dyspnoea at rest and tachycardia. Pulmonary embolism was diagnosed because of which the patient was treated at the Pulmonary Disease Ward of the Institute of Tuberculosis and Lung Diseases in Warsaw, and then underwent rehabilitation of cognitive disorders (amniotic syndrome, anomic aphasia) in the Neurology and Rehabilitation Ward at the Institute of Psychiatry and Neurology The results of neuropsychological examination indicated regressing, relatively isolated, memory disturbances in the form of memory deficit (including difficulty remembering new information and inability to retrieve engrams previously preserved in the memory). The patient returned to work as an office worker. Currently ( 9 years after the disease onset), neurological examination of the patient shows no abnormalities except for minor persistent cognitive impairments and epilepsy. The patient is treated with gabapentin (3600 $\mathrm{mg}$ daily), levetiracetam (1500 mg twice a day) and lacosamide (200 mg per day) with satisfactory effects. Seizures' control is quite good; their average number is a maximum of 1 in 2 per month with long seizure-free periods. The factors causing LE were not confirmed (no onconeuronal antibodies and surface antigens were found at the disease onset). Clinical picture with predominant memory impairment and epilepsy could match LE with anti-NMDA antibodies. chwy i okolic ust. Ze względu na brak skuteczności fenytoiny włączono topiramat doustnie, we wzrastających dawkach w ciągu kolejnych dni do 2 x $500 \mathrm{mg}$. Po kolejnym zapisie EEG (ryc. III) dodano do farmakoterapii karbamazepinę 2 x 100 mg (w dawce wzrastającej do 600 $\mathrm{mg} /$ dobę).

W trakcie hospitalizacji u pacjentki wystąpiła duszność spoczynkowa i tachykardia. Rozpoznano zatorowość płucną, z powodu której pacjentka była leczona na Oddziale Chorób Płuc Instytutu Gruźlicy i Chorób Płuc w Warszawie. Następnie przebyła rehabilitację zaburzeń funkcji poznawczych (zespołu amnestycznego, anomii) na Oddziale Rehabilitacji Neurologicznej IPiN. Wyniki badania neuropsychologicznego wskazywały na wycofujące się, względnie izolowane, zaburzenia pamięci w postaci deficytu zapamiętywania nowych informacji oraz aktualizacji utrwalonego przedchorobowo śladu pamięciowego. Pacjentka wróciła do poprzednio wykonywanej pracy jako pracownik biurowy. Obecnie (9 lat od zachorowania) nie ma nieprawidłowości w badaniu neurologicznym, poza niewielkimi, utrzymującymi się zaburzeniami funkcji poznawczych i padaczką. Pacjentka jest leczona gabapentyną (3600 mg/dobę), lewetyracetamem (1500 mg dwa razy na dobę) i lakozamidem (200 $\mathrm{mg}$ /dobę) z dość dobrym efektem. Kontrola napadów jest dość dobra, średnia liczba wynosi maksymalnie jeden na 2 miesiące, $\mathrm{z}$ długimi okresami miesięcznymi bez incydentów. Pacjentka nie miała potwierdzonej etiologii LE ( $w$ czasie zachorowania nie oznaczono przeciwciał onkoneuronalnych i przeciwko antygenom powierzchniowym). Obraz kliniczny z dominującymi zaburzeniami pamięci i padaczką mógł odpowiadać LE z przeciwciałami anty-NMDA. 
A

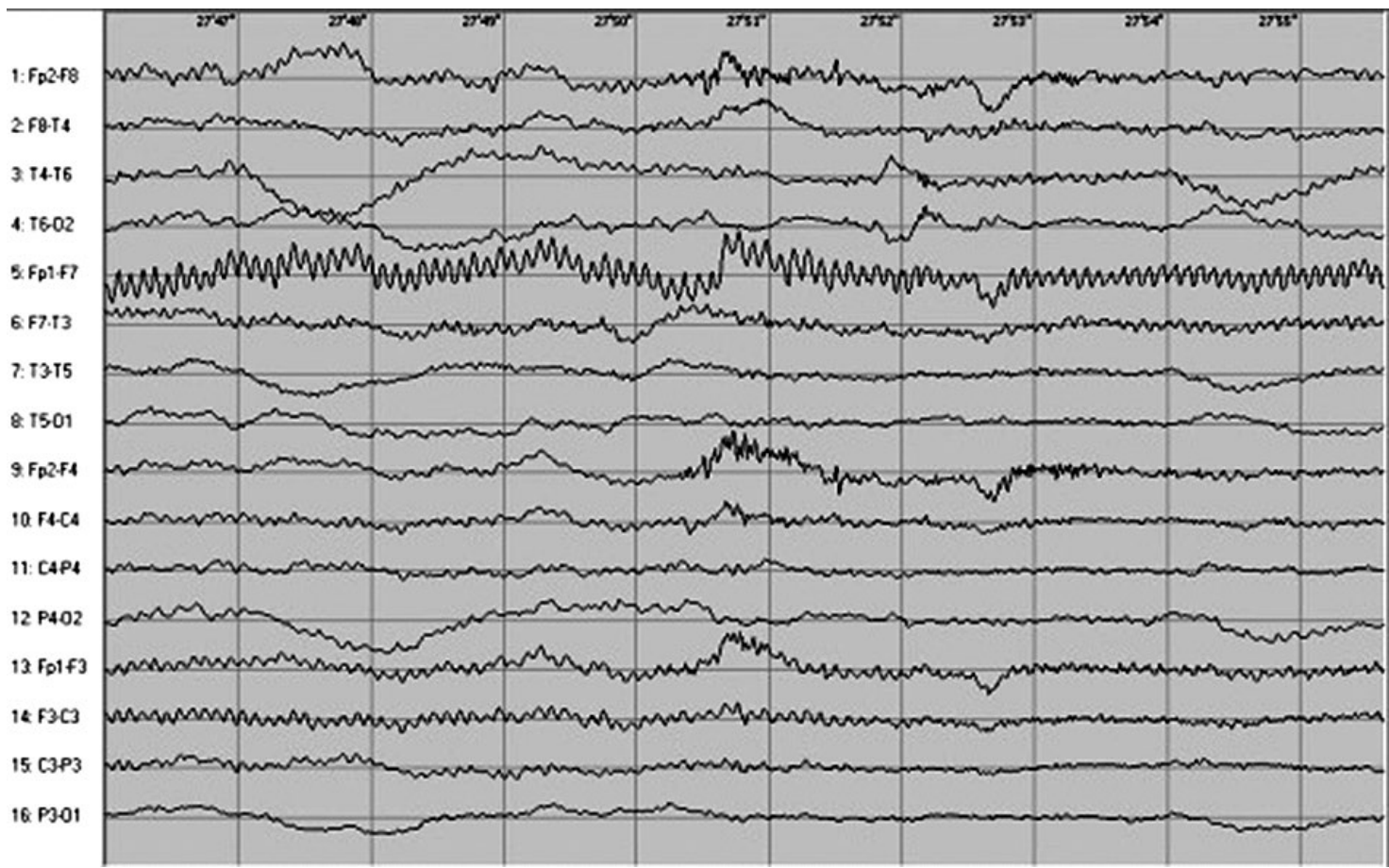

B

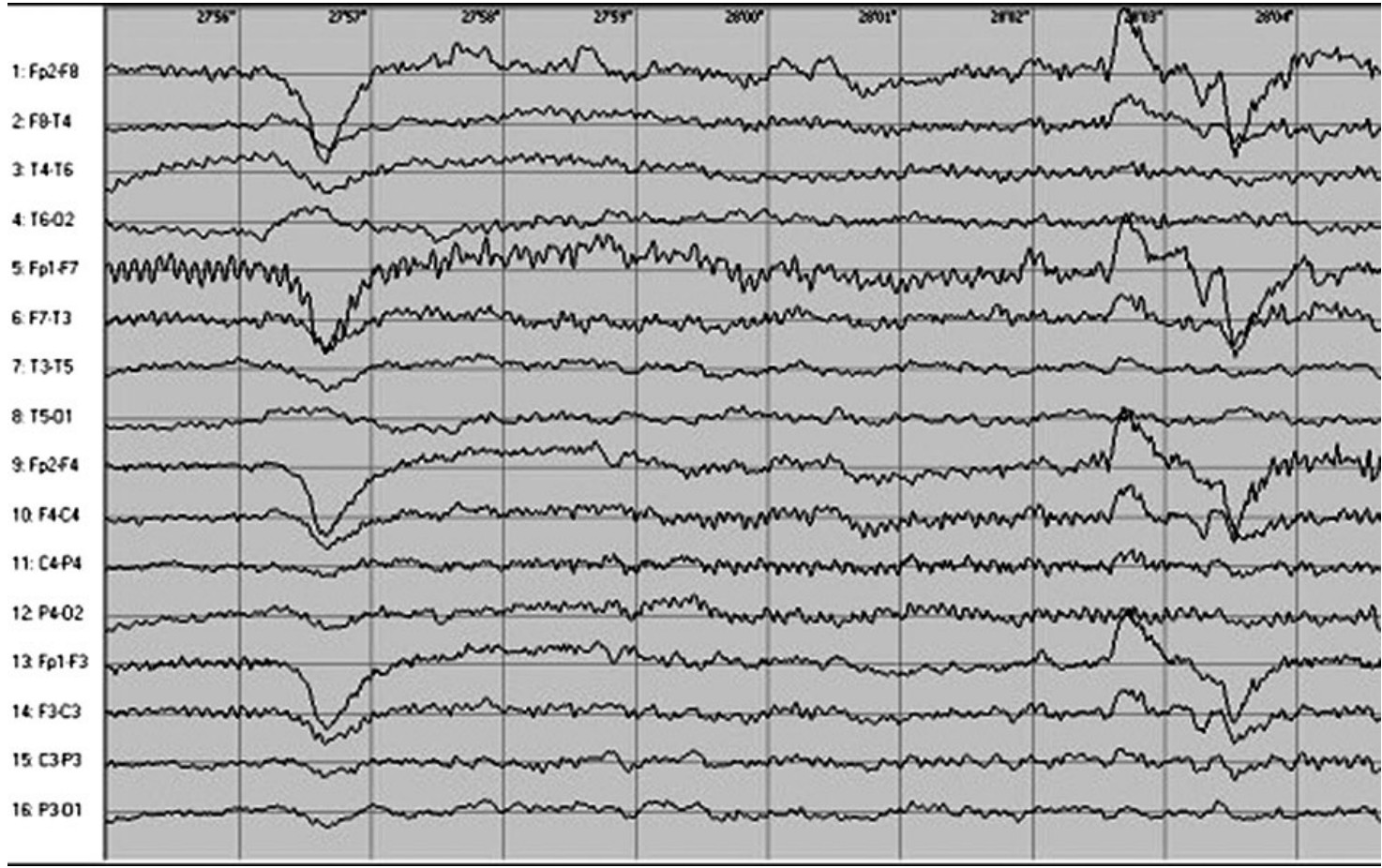

Figure III. Longitudinally recorded awake EEG activity of the patient made on the $19^{\text {th }}$ day of disease. The interparoxysmal recordings showed in all electrodes $2-3 \mathrm{~Hz}$ free waves, single and in groups, against the generally changed basic activity. Records (video EEG) of clinical seizures beginning with paroxysmal activity in left anterior temporal lobe (A, B), then moving to the right temporal lobe (C, D) with visible arthroplasty of muscles due to oromandibular tremor (E)

Rycina III. Zapis EEG pacjentki z 19. dnia choroby wykonany w czuwaniu, montaż podłużny. W zapisie międzynapadowym we wszystkich odprowadzeniach widoczne były pojedyncze i w grupach fale wolne 2-3 Hz na tle ogólnie zmienionej czynności podstawowej. Rejestracja napadów klinicznych (w wideo-EEG) rozpoczynających się czynnością napadową w lewej okolicy przednio-skroniowej (A, B), następnie przechodzącą do prawej okolicy skroniowej (C, D), z widocznymi artefaktami czynności mięśni z powodu drgawek oromandibularnych (E) 
C
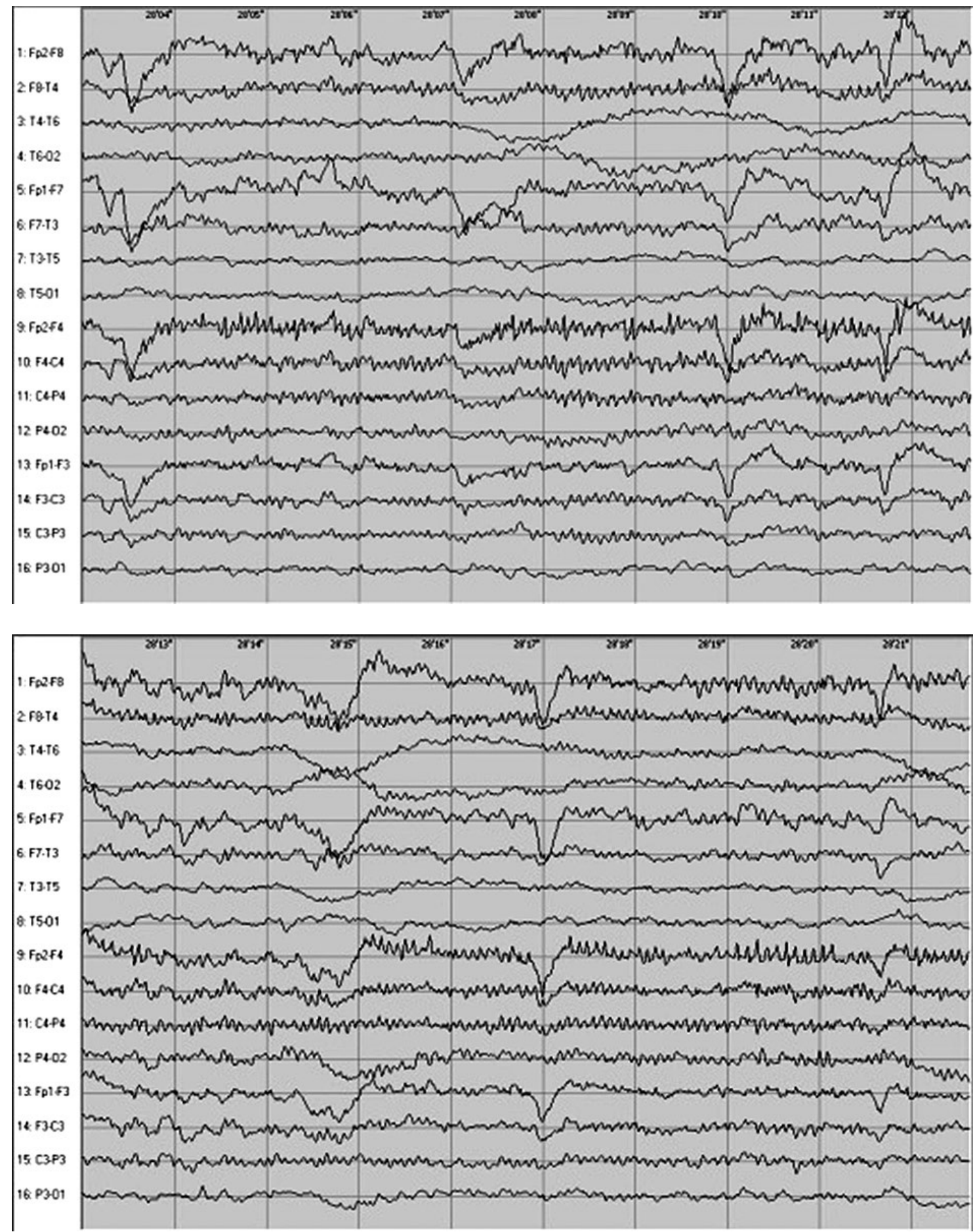

Figure III. Cont.

Rycina III. Cd. 
E

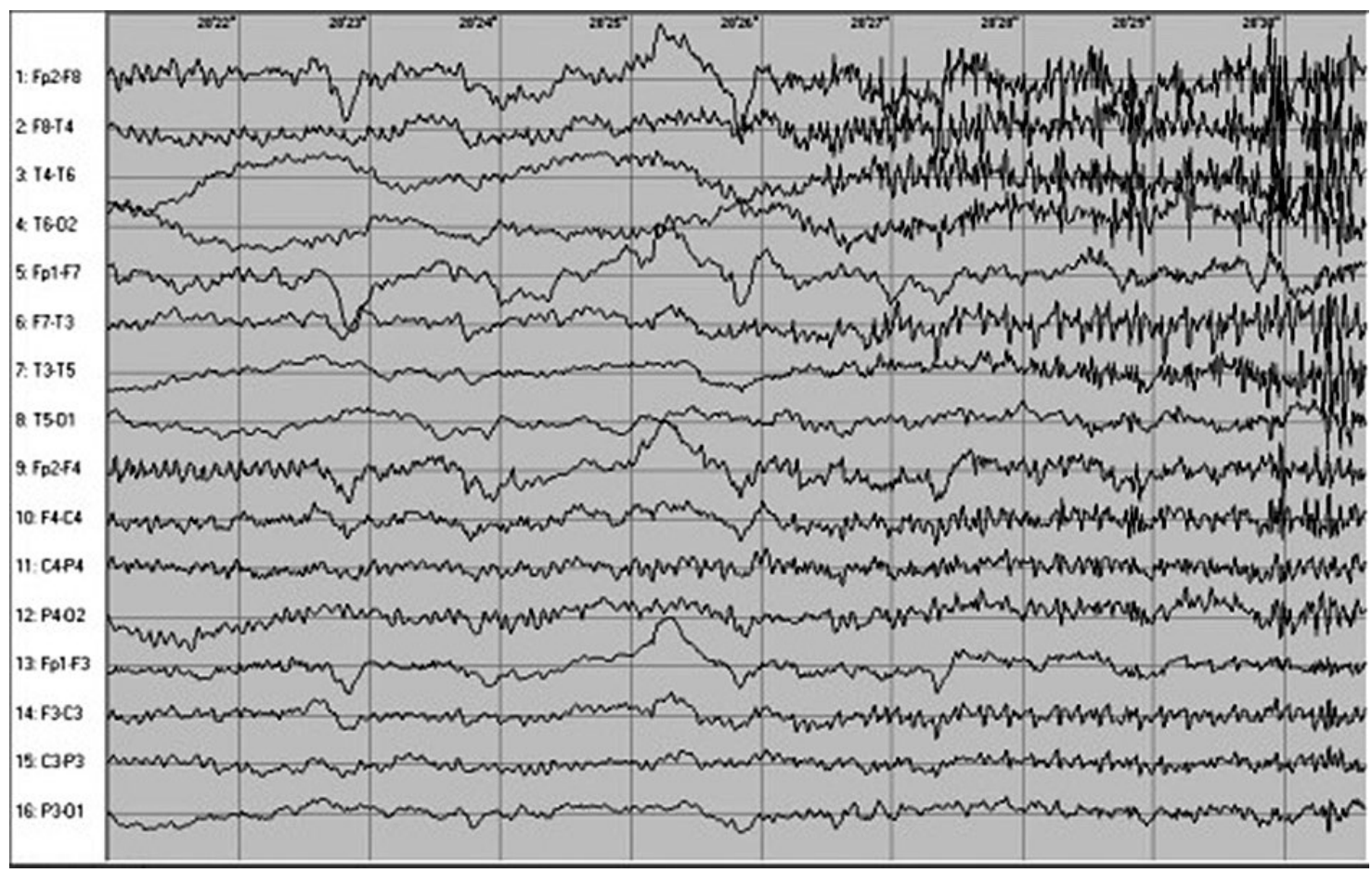

Figure III. Cont.

Rycina III. Cd.

\section{COMMENT}

Limbic encephalitis was described for the first time in 1960 as a clinical and pathological syndrome in adults [1]. Brierley et al. and Corsellis et al. [1,2] were the first to report the cases of six patients aged 50-80 years who died of a progressive neurological disorder characterized by disturbances in episodic memory, mood disorders and epilepsy. Post-mortem tests revealed chronic inflammatory processes with perivascular lymphocytic infiltrates, microglial clusters, and astrocytic gliosis within the hook and Brodmann area 28 , the amygdala, the islands of Calleja, and angular gyrus. The autopsy performed by Corsellis et al. [1] showed that four out of six patients had tumour outside the nervous system (in three cases it was lung cancer), which led to the concept of paraneoplastic limbic encephalitis (PLE). Paraneoplastic limbic encephalitis is mainly associated with small-cell lung cancer (40\%), testicular embryonal carcinoma (20\%), breast cancer (8\%), Hodgkin's lymphoma, thymus and immature teratoma [3]. Having analysed fifty PLE cases, Gultekin et al. found that neurological symptoms can anticipate oncological diagnosis in 2/3 of patients (with an average of 3.5 months) [4]. It is currently believed that this disease occurs with a similar frequency and affects both sexes to the same extent.

\section{KOMENTARZ}

Limbiczne zapalenie mózgu zostało opisane po raz pierwszy w 1960 r. jako zespół kliniczno-patologiczny występujący u osób dorosłych [1]. Brierley i wsp. oraz Corsellis i wsp. $[1,2]$ pierwsi opublikowali przypadki 6 chorych w wieku 50-80 lat, którzy zmarli w przebiegu postępującego schorzenia neurologicznego charakteryzującego się zaburzeniami pamięci epizodycznej, zaburzeniami nastroju i napadami padaczkowymi. Badania pośmiertne wykazały obecność przewlekłego procesu zapalnego z okołonaczyniowymi naciekami limfocytarnymi, zgrupowaniami mikrogleju oraz gliozą astrocytarną w obrębie haka i zakrętu hipokampa, ciała migdałowatego, wyspy, zakrętu kątowego. U 4 z 6 chorych Corsellis i wsp. [1] rozpoznali w badaniu sekcyjnym obecność guza poza układem nerwowym (w 3 przypadkach był to nowotwór płuc), co dało początek koncepcji paranowotworowego limbicznego zapalenia mózgu (paraneoplastic limbic encephalitis - PLE). Paranowotworowe limbiczne zapalenie mózgu jest związane głównie z drobnokomórkowym rakiem płuc (40\%), zarodkowymi nowotworami jądra (20\%), rakiem sutka (8\%), ziarnicą złośliwą, grasiczakiem i potworniakiem niedojrzałym [3]. Po przeanalizowaniu 50 przypadków PLE Gultekin i wsp. stwierdzili, że objawy neurologiczne mogą wyprzedzać rozpoznanie nowotworu nawet u $2 / 3$ chorych, z medianą 3,5 miesiąca [4]. Obecnie przyjmuje się, że choroba ta występuje z podobną częstością u obu płci. 


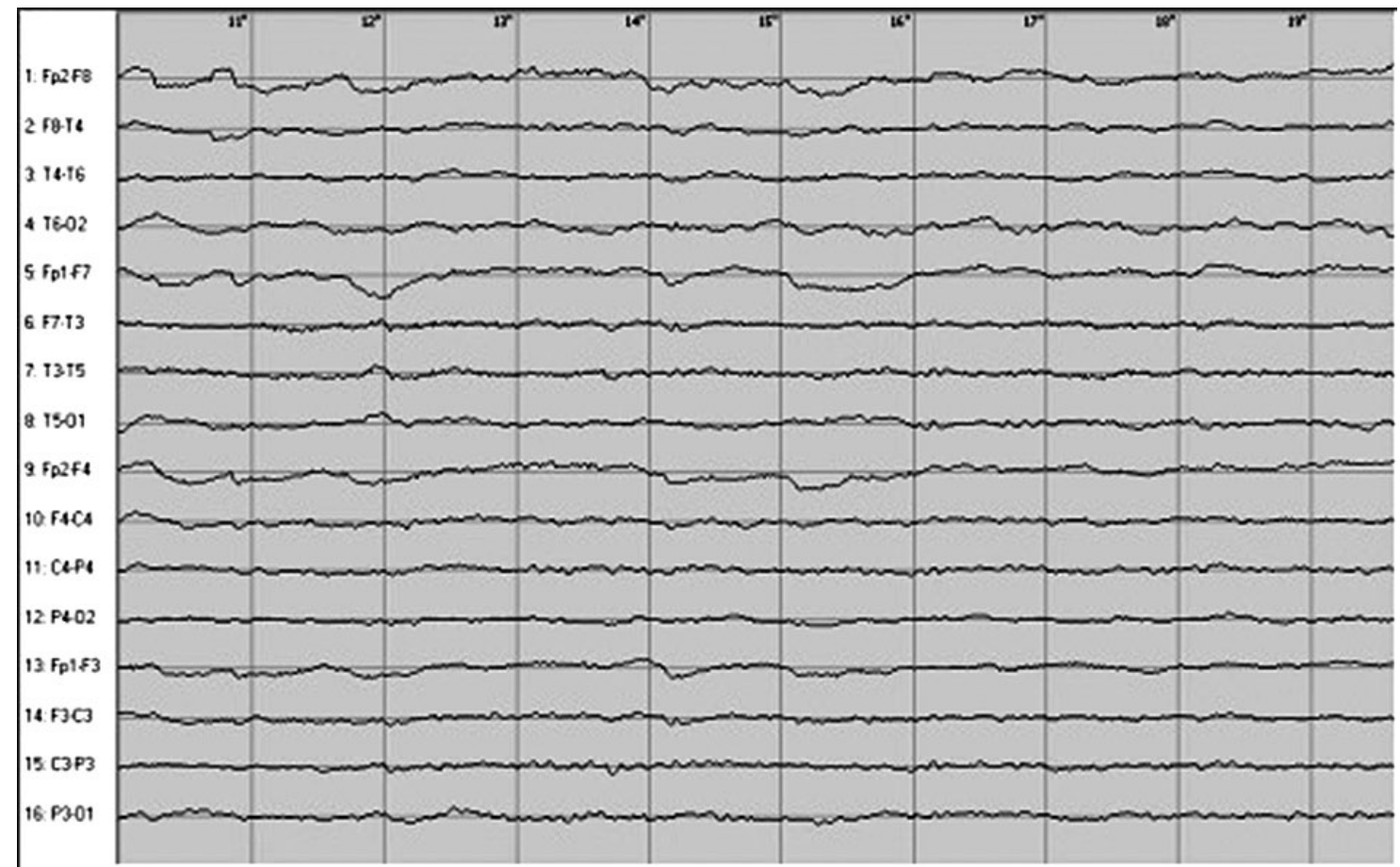

Figure IV. Longitudinally recorded awake EEG activity after status epilepticus abated

Rycina IV. Zapis EEG po ustąpieniu stanu padaczkowego, wykonany w czuwaniu, montaż podłużny

Limbic encephalitis symptoms include short-term memory disturbance and orientation, behavioural and mood disorders, while other cognitive functions remain relatively preserved $[2,4]$. The following disturbances may also occur: sleep disturbances, psychotic symptoms, paralysis or limb paresis and focal seizures with consciousness disorders or generalized tonic-clonic seizures $[5,6]$. As pathological process affects hypothalamus, hyperthermia, hyperthyroidism and hypopituitarism (deficiency of hormones normally produced by the pituitary gland) may occur [7]. Typical clinical symptoms in the form of subacute (rarely acute) onset of cognitive disorders, seizures and psychiatric disorders (behavioural and affective disorders, especially emotional lability, depressive disorders, anxiety attacks and psychosis) backed up with characteristic magnetic resonance imaging and computed tomography scans showing pathologically increased signal intensity of one or both medial temporal lobes on T2-weighted images and FLAIR sequence, provide the basis for diagnosis of LE [8]. The symptoms necessary for the diagnosis of LE defined by Bien and Vincent in 2013 are summarized in Table 1.

In terms of aetiology, we divide LE into non-infectious (a para nitrogen syndrome primarily associated with small cell lung cancer) and infectious cases (caused by herpes simplex virus). Other cases of autoimmune diseases have also been reported such as non-paraneo-
Objawy LE obejmują przede wszystkim zaburzenia pamięci krótkotrwałej, orientacji, zachowania i zaburzenia nastroju, przy względnie zachowanych innych funkcjach poznawczych $[2,4]$. Obserwuje się również zaburzenia snu, objawy psychotyczne, porażenia lub niedowłady oraz napady padaczkowe, zwykle ogniskowe z zaburzeniami świadomości lub uogólnione toniczno-kloniczne $[5,6]$. Z powodu zajęcia przez proces patologiczny podwzgórza może wystąpić hipertermia, żarłoczność i hipopituitaryzm (niedobór hormonów przysadki mózgowej) [7]. Podstawę do rozpoznania LE stanowią charakterystyczne objawy kliniczne w postaci podostrego, rzadziej ostrego początku zaburzeń poznawczych, napadów padaczkowych i zaburzeń psychiatrycznych (zaburzeń zachowania, afektywnych, zwłaszcza odhamowania i labilności emocjonalnej, a także lęku, psychozy), poparte charakterystycznym obrazem MRI w postaci patologicznego wzrostu intensywności sygnału przyśrodkowej części płata skroniowego jedno- lub obustronnie, w obrazach T2-zależnych i w sekwencji FLAIR [8]. Zdefiniowane przez Biena i Vincent w 2013 r. objawy konieczne do rozpoznania LE przedstawiono w tabeli 1.

Pod względem etiologicznym wyróżnia się przypadki nieinfekcyjne LE (o charakterze zespołu paranowotworowego, związanego głównie z rakiem drobnokomórkowym płuc) oraz przypadki infekcyjne LE (spowodowane przez wirusa opryszczki pospolitej). Opisano również przypadki związane z chorobami autoimmunologicznymi - niepa- 
A

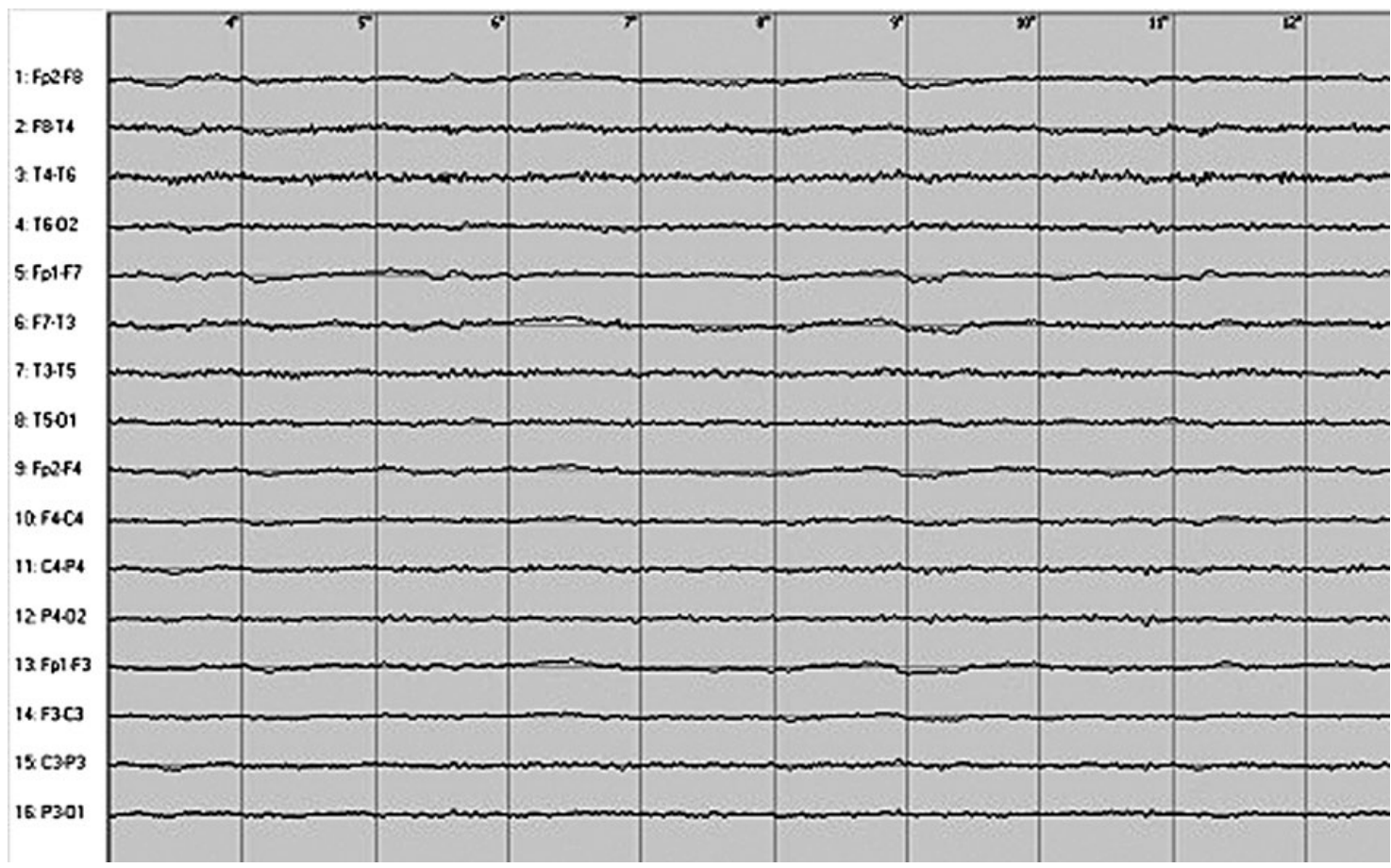

B

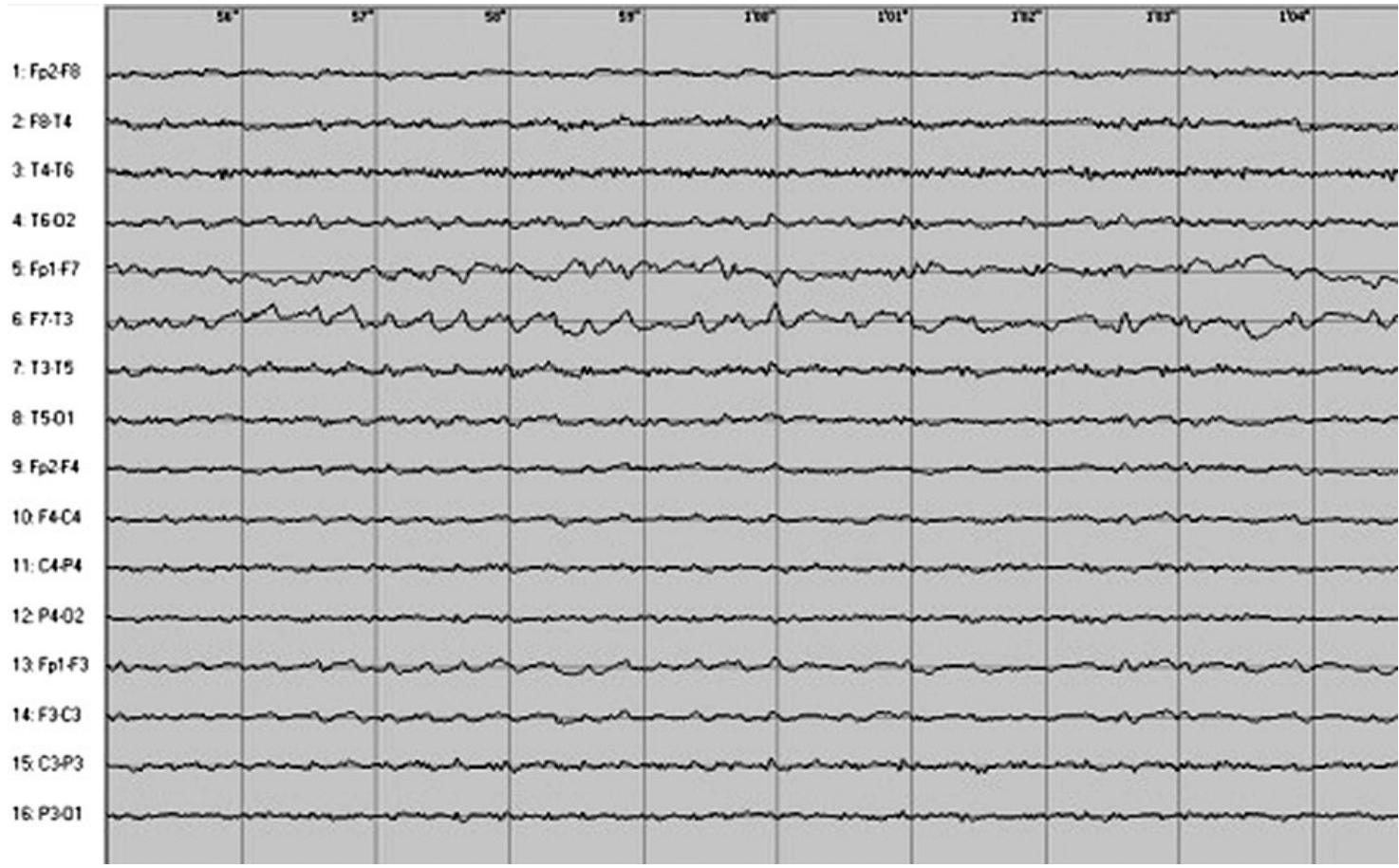

Figure V. Longitudinally recorded control awake EEG activity. Visible basic EEG activity with normal spatial differentiation (A). The recording of slow wave discharges and spike-and-wave complexes in the left frontal and temporal lobe lasting approximately 10 seconds (B, C) and short spike-and-wave discharges in this location (D)

Rycina V. Kontrolne badanie EEG wykonane w czuwaniu, montaż podłużny. Widoczna czynność podstawowa EEG o prawidłowym zróżnicowaniu przestrzennym (A). Rejestracja wyładowań napadowych fal wolnych oraz zespołów fali ostrej z falą wolną w lewej okolicy czołowo-przednioskroniowej trwających około 10 sekund (B, C) oraz krótkich wyładowań zespołów fali ostrej z falą wolną w tej lokalizacji (D) 
C

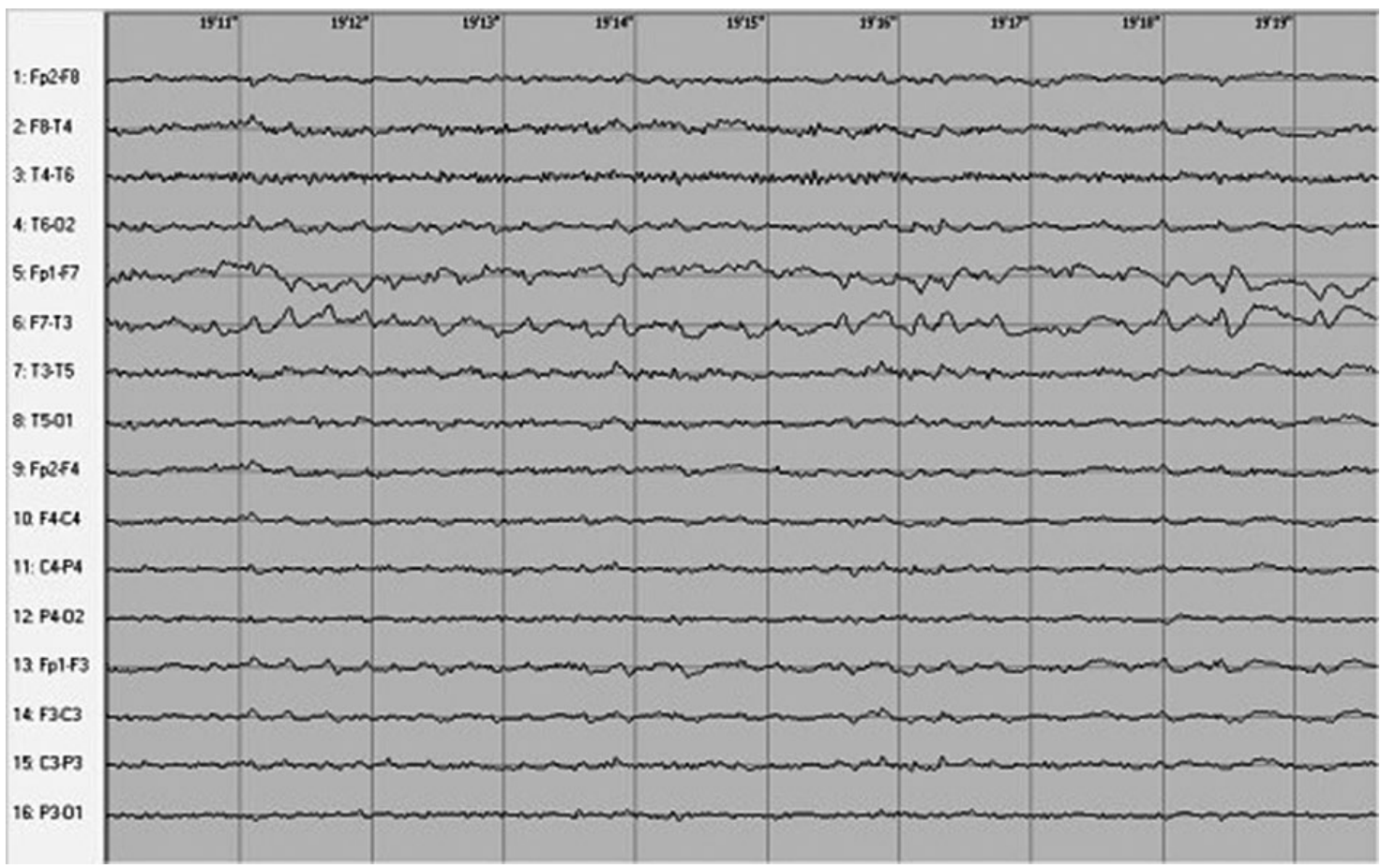

D

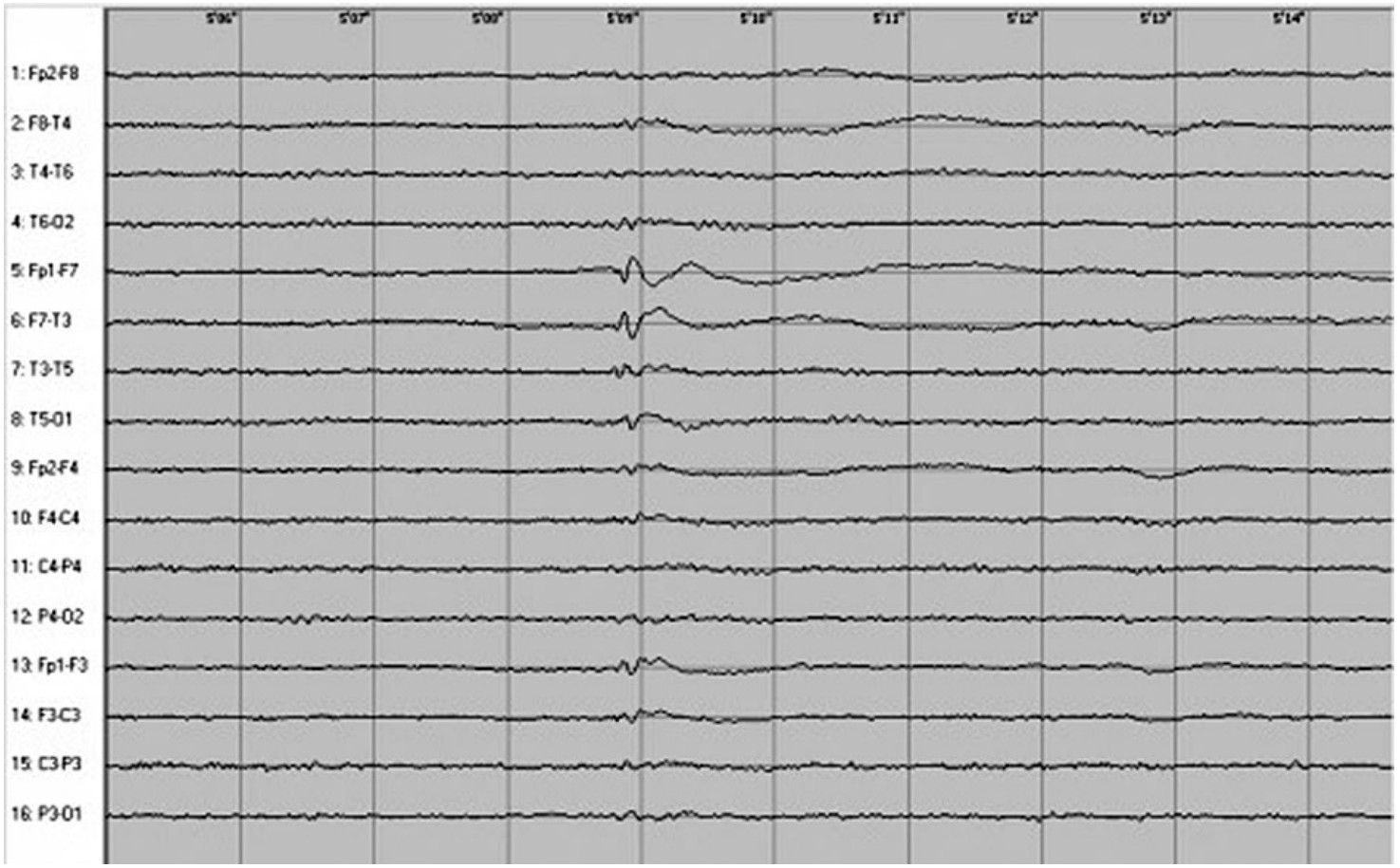

Figure V. Cont.

Rycina V. Cd.

plastic variants of limbic encephalitis (NPLE), where the presence of antibodies directed against cell membrane antigens is noted. Ultimately, based on clinical picture, changes in magnetic resonance imaging and CT scans, the absence of tumour, and long-term patients' observation, a group of other NPLEs were isolated, where ranowotworowe warianty LE (non-paraneoplastic limbic encephalitis - NPLE), w których obserwuje się obecność przeciwciał skierowanych przeciwko antygenom błony komórkowej. Ostatecznie na podstawie obrazu klinicznego, zmian w obrazie MRI, nieobecności nowotworu i długofalowej obserwacji chorych wyodrębniono grupę 
Non-paraneoplastic variant of limbic encephalitis - case report

Nieparanowotworowy wariant limbicznego zapalenia mózgu - opis przypadku

Table 1. Symptoms necessary to diagnose limbic encephalitis summarized by Bien and Vincent in 2013

Tabela 1. Objawy konieczne do rozpoznania limbicznego zapalenia mózgu zebrane przez przez Biena i Vincent w 2013 r.

Recent onset of the disease $(<12$ weeks)/

Niedawny początek choroby ( $<12$ tygodni)

Confirming that the limbic system has been affected (the presence of at least one symptom in clinical picture, such as short-term memory disorders and/or temporal lobe seizures and/or affective disorders)/

Stwierdzenie zajęcia układu limbicznego (obecność co najmniej jednego objawu w obrazie klinicznym, takiego jak zaburzenia pamięci krótkotrwałej i/lub napady skroniowe, i/lub zaburzenia afektywne)

At least one morphological symptom (i.e. neuropathological examination reveals chronically active inflammatory processes

in medial temporal lobe and/or the presence of a tumour diagnosed within 5 years of the occurrence of neurological symptoms,

and/or the presence of autoantibodies, and/or the signs of inflammation in medial temporal lobe in MRl, which cannot be explained

otherwise) (9-11)/

Co najmniej jeden objaw z badań morfologicznych (w badaniu neuropatologicznym stwierdzenie przewlekłego zapalenia

przyśrodkowej części płata skroniowego i/lub obecność guza zdiagnozowanego w ciągu 5 lat od wystąpienia objawów

neurologicznych, i/lub obecność autoprzeciwciał, i/lub w badaniu MRI cechy zapalenia w przyśrodkowej części płata skroniowego,

kłórych nie można wyjaśnić inaczej) (9-11)

the above-mentioned antibodies are not present. In such cases, there were no symptoms of acute febrile illness, and the leading symptom of this variant is seizure that originates in the temporal lobe. Non-paraneoplastic variants of limbic encephalitis are examples of potentially reversible LE variants [12].

The most frequent infectious cause of this disease is herpes simplex virus (HSV), including human herpes virus 6 [13].

Non-infectious LE is paraneoplastic limbic encephalitis (PLE) [14]. In the 1980s and 1990s, the presence of antibodies in the serum of patients having neurological symptoms and neoplastic disease cross-reacting with tumour tissue and nerve cells was discovered. These antibodies were called 'onconeural antibodies' [5]. The first detected antibodies were called anti-Hu (associated with small cell lung cancer (SCLC)), followed by anti-Ma2 (associated with testicular carcinoma), anti-Yo (associated with ovarian, breast, and uterus cancers), anti-Ri (associated with breast cancer and SCLC) [15-18]. The pathogenetic mechanism that leads to onconeuronal antibody formation has not been thoroughly investigated. It is probable that cancer cells present antigens that stimulate the formation of antibodies cross-reacting with neurons' intracellular antigens. Similar mechanism causes the activation of cytotoxic T lymphocytes, which attack and destroy neurons, thus leading to the occurrence of neurological symptoms. There are also NPLE associated with autoimmune diseases with antibodies directed against a human cell membrane antigens, such as voltage-gated potassium channel antibodies (VGKC) $[3,5,19]$, antibodies directed against glutamic acid decarboxylase (GAD) $[20,21]$, antibodies that target novel cell membrane antigen (nCMAg) [22] and antibodies directed against $\mathrm{N}$-methyl-D-aspartate receptor (NMDAR) [23]. It is worth noting that some patients, in which these antibodies are detected in the LE course, also develop cancers. Antibodies against proteins alone that form innych NPLE, w których nie stwierdza się wymienionych przeciwciał. Przypadki te nie były poprzedzone objawami ostrej infekcji gorączkowej, a wiodącym symptomem wariantu są skroniowe napady padaczkowe. Nieparanowotworowe warianty LE są przykładem potencjalnie odwracalnych wariantów LE [12].

Najczęstszą przyczyną zakaźną powodującą tę chorobę jest wirus opryszczki pospolitej (herpes simplex virus HSV), w tym ludzki wirus herpes typu 6 [13].

Niezakaźne LE mają charakter zespołu paranowotworowego (PLE) [14]. W latach 80. i 90. ubiegłego wieku dokonano odkryć przeciwciał obecnych w surowicy krwi chorych z objawami neurologicznymi i wspólistniejącą chorobą nowotworową, reagujących krzyżowo z tkanką guza i komórkami nerwowymi. Przeciwciała te określono mianem przeciwciał onkoneuronalnych [5]. Pierwsze wykryte przeciwciała nazwano anty-Hu (związane z rakiem drobnokomórkowym płuc; SCLC - small cell lung cancer). Kolejnymi odkrytymi przeciwciałami były anty-Ma2 (związane z guzami jąder), anty-Yo (związane z nowotworami jajnika, piersi, macicy), anty-Ri (związane z rakiem sutka i SCLC) [15-18]. Mechanizm patogenetyczny powstawania przeciwciał onkoneuronalnych nie został dokładnie poznany. Prawdopodobnie komórki guza prezentują antygeny, które stymulują tworzenie przeciwciał reagujących krzyżowo $\mathrm{z}$ antygenami wewnątrzkomórkowymi neuronów. W podobnym mechanizmie dochodzi również do aktywacji cytotoksycznych limfocytów T, które atakują i niszczą neurony, co jest przyczyną występowania objawów neurologicznych. Istnieją również związane z chorobami autoimmunologicznymi nieparanowotworowe warianty LE (NPLE), w których występują takie przeciwciała skierowane przeciwko antygenom błony komórkowej, jak: przeciwciała przeciwko bramkowanym napięciem kanałom potasowym (voltagegated potassium channel antibodies - VGKC) $[3,5,19]$, przeciwciała przeciwko dekarboksylazie kwasu glutaminowego (glutamic acid decarboxylase - GAD) [20, 21], przeciwciała przeciwko nowym antygenom błony komórkowej (novel cell membrane antygen - nCMAg) [22] i przeciwciała prze- 
the potassium channel (alpha subunit) are rarely detected. Most frequently detected antibodies are those directed against the LGI1 protein, which plays an important role in synaptic transmission as it binds to preand post-synaptic protein complexes [24-29], against the CASPR2-associated protein contaktin-2. Limbic encephalitis may have some characteristic medical signs depending on the type of antibodies present. Limbic encephalitis associated with anti-LGI1 antibodies is characterized by epileptic seizures in the form of dystonia affecting lips and upper limbs resistant to treatment, memory disorders and hyponatremia. LE with anti-CASPR2 antibodies is associated with damage to the peripheral nervous system and Morvan's syndrome (myoclonus, contractions of muscles, hyperhidrosis, insomnia and delirium) [11]. Typical syndromes also occur in LE with anti-NMDA antibodies positive patients and include mental disorders, epilepsy and dystonia affecting lips. In paraneoplastic variant, the disease usually affects young women with ovarian carcinoma, often with teratomas, while in non-paraneoplastic variant, it affects both sexes to the same extent. Typical antibody associated with LE in the course of lung cancer, breast cancer and thymus is anti-AMPAR [11]. Furthermore, the GABAB receptor antibodies clinically characterized by epileptic seizures and status epilepticus should also be mentioned [11]. In several cases, the presence of the GluEepsilon2 and NMDAR antibodies was detected in serum and cerebrospinal fluid [30-34].

In the diagnosis of LE, the result of computed tomography of the brain is usually normal. MRI abnormalities occur in about $60 \%$ of PLE patients and sensitivity of the method increases when the FLAIR sequence is used. Changes in the form pathological increase in signal intensity of one or both medial temporal lobes in T2 and FLAIR sequence are best seen in the frontal plane. In the $\mathrm{T} 1$ sequence, the temporal-limbic area may be hypointense and atrophic, and rarely enhances after contrast injection [16]. In PLE variants, extratemporal lobe epilepsy was also reported [26]. If MR imaging is normal, fluorodeoxyglucose-positron emission tomography (FDG-PET) should show increased signal in medial temporal lobe in acute inflammatory phase $[35,36]$. EEG may show paroxysmal discharge in temporal area or, most frequently, slow waves in temporal lobe one or both sides [33]. The cerebrospinal fluid analysis remains mandatory to support the diagnosis (inflammatory features in 80\% LE) [37]. In LE patients, neuropathological examination shows neuronal loss in the amygdala and hippocampal area, perivascular lymphocytic infiltrates, microglial aggregation, and glycosuria $[35,36]$.

As far as differential diagnosis is concerned, the following disease entities should be taken into account: ciwko receptorowi $N$-metylo- $D$-asparaginianu ( $N$-methyl-D-aspartate receptor - NMDAR) [23]. Warto zaznaczyć, że u części chorych, u których wykrywa się te przeciwciała, $\mathrm{w}$ przebiegu LE również występują nowotwory. Rzadko wykrywa się przeciwciała przeciwko samym białkom tworzącym kanał potasowy (podjednostka a), najczęściej przeciwko białku LGI1, które odgrywa istotną rolę w transmisji synaptycznej poprzez udział $\mathrm{w}$ tworzeniu pre- i postsynaptycznych kompleksów białkowych [24-29], przeciwko białku związanemu z kontaktyną (CASPR2) i kontaktyną 2 (contaktin-2). Obraz chorobowy LE może mieć pewne charakterystyczne cechy w zależności od rodzaju występujących przeciwciał. Limbiczne zapalenie mózgu z przeciwciałami anty-LGIl charakteryzuje się napadami padaczkowymi w postaci ogniskowych napadów drgawek ust i kończyny górnej odpornych na leczenie, zaburzeń pamięci i hiponatremii, natomiast LE z przeciwciałami anty-CASPR2 związany jest $\mathrm{z}$ uszkodzeniem obwodowego układu nerwowego i zespołem Morvana (mioklonie, skurcze mięśni, hiperhydroza, bezsenność, majaczenie) [11]. Charakterystyczny obraz chorobowy występuje też w LE z przeciwciałami anty-NMDA. W obrazie klinicznym dominują zaburzenia psychiczne i padaczka, charakterystyczne są ruchy dystoniczne ust. Choroba w wariancie paranowotworowym dotyczy zwykle młodych kobiet z guzami jajnika, często z potworniakami, $\mathrm{w}$ wariancie nieparanotworowym dotyczy równie często obu płci. Charakterystycznym przeciwciałem związanym z LE w przebiegu guzów płuca, gruczołu piersiowego i grasicy jest anty-AMPAR [11]. Należy wymienić ponadto przeciwciała przeciwko receptorom GABAB, klinicznie charakteryzujące się napadami padaczkowymi i stanami padaczkowymi [11]. W kilku przypadkach w surowicy krwi i płynie mózgowo-rdzeniowym chorych stwierdzono obecność przeciwko GluEepsilon2 oraz NMDAR [30-34].

$\mathrm{W}$ procesie diagnostycznym LE wynik tomografii komputerowej mózgowia jest zazwyczaj prawidłowy. Nieprawidłowości w badaniu MRI występują u około $60 \%$ chorych z PLE, a czułość metody wzrasta w przypadku zastosowania sekwencji FLAIR. Zmiany w postaci patologicznego wzrostu intensywności sygnału przyśrodkowej części płata skroniowego jedno- lub obustronnie w sekwencji T2 i FLAIR są najlepiej widoczne w płaszczyźnie czołowej. W sekwencji T1 obszar skroniowo-limbiczny może być hipointensywny i atroficzny, rzadko ulega wzmocnieniu po podaniu kontrastu [16]. W wariantach PLE dodatkowo opisywano zajęcie kory pozaskroniowej [26]. W przypadku prawidłowego obrazu MRI pozytronowa tomografia emisyjna z zastosowaniem fluorodeoksyglukozy (fluorodeoxyglucosepositron emission tomography - FDG-PET) powinna wykazać w ostrej fazie zapalenia wzmożony sygnał znacznika w przyśrodkowej części płata skroniowego [35, 36]. EEG może uwidocznić wyładowania napadowe w okolicach skroniowych lub najczęściej fale wolne w okolicach skroniowych, jedno- lub obustronnie [33]. Badanie płynu mózgowo-rdzeniowego ma znaczenie wspomagające (cechy zapalenia 
infections (HSV-1 and HSV-2, VZV, enteroviruses, adenoviruses, HIV, CMV, EBV, West Nile virus, listeriosis, neuroborreliosis, neurosyphilis), ADEM (acute disseminated encephalomyelitis), neurodegenerative diseases (Creutzfeldt-Jakob's disease, progressive Alzheimer's disease, dementia with Lewy bodies), deficiency diseases/ toxins/drugs (thiamine deficiency, alcohol, chemotherapy [methotrexate], lithium salts), metabolic disorders (hepatic encephalopathy, nephritic syndrome, electrolyte disorders), systemic diseases (Behçet's disease, Sjögren's syndrome, SLE (systemic lupus erythematosus), primary vasculitis), primary/secondary CNS tumours (gliomas, metastases, primary lymphomas, intravascular lymphomas).

The most crucial step in LE treatment is to finding factors causing limbic inflammation as early as possible. There are no detailed guidelines for LE treatment; it is essential to use immunosuppressive drugs and symptomatic treatment. In LE with onconeuronal antibodies, the treatment involves cancer removal and/or treatment and immunotherapy. Methylprednisolone (500-1000 mg per day for 5 days), immunoglobulin (intravenously, $2 \mathrm{~g}$ per $\mathrm{kg}$ of body weight for 5 days) and plasmapheresis can be used in autoimmune LE. If there is improvement, treatment can be repeated every 6-8 weeks or prednisone can be given orally (1 mg per kg of body weight for several months, usually 3-6 months in full dose). If there is no improvement, rituximab $\left(375 \mathrm{mg} / \mathrm{m}^{2}\right)$ or cyclophosphamide $\left(750 \mathrm{mg} / \mathrm{m}^{2}\right.$ \pm IVG $2 \mathrm{~g}$ per $\mathrm{kg}$ of body weight in 8 cycles) or combination therapy can be administered. About $60-80 \%$ of patients with LE respond well to treatment and mortality rate is low (less than $4 \%$ of cases). It should be kept in mind that in the case of LE caused by 'classic' onconeuronal antibodies the treatment options are poor as the condition of less $10 \%$ of patients improves (the prognosis is better for patients who received rituximab) [38]. Furthermore, anti-epileptic treatment in LE is usually ineffective. Seizures and/or status epilepticus usually respond well to immunosuppressive therapy. It is also reported that thiopental treatment in LE caused by anti-NMDA antibodies may increase the seizure threshold and should be contraindicated in such cases [39]. w 80\% LE) [37]. Neuropatologicznie u chorych z LE stwierdza się ubytek neuronów w obrębie hipokampa i ciała migdałowatego, okołonaczyniowe nacieki limfocytarne, zgrupowania mikrogleju oraz gliozę $[35,36]$.

W diagnostyce różnicowej należy wziąć pod uwagę: infekcje (HSV-1 i HSV-2, wirus ospy wietrznej i półpaśca, enterowirusy, adenowirusy, HIV, CMV, EBV, wirus Zachodniego Nilu, listeriozę, neuroboreliozę, kiłę ośrodkowego układu nerwowego), ostre rozsiane zapalenie mózgu i rdzenia (acute disseminated encephalomyelitis - ADEM), choroby neurodegeneracyjne (choroba Creutzfeldta-Jakoba, szybko postępująca choroba Alzheimera, otępienie z ciałami Lewy'ego), choroby niedoborowe, toksyny i leki (niedobór tiaminy, alkohol, chemioterapia [metotreksat], sole litu), choroby metaboliczne (encefalopatia wątrobowa, nerczycowa, zburzenia elektrolitowe), choroby układowe (choroba Behçeta, zespół Sjögrena, toczeń rumieniowaty układowy [systemic lupus erythematosus - SLE], pierwotne zapalenie naczyń), pierwotne i wtórne nowotwory OUN (glejaki, przerzuty, pierwotne chłoniaki, chłoniaki wewnątrznaczyniowe).

W procesie leczniczym LE najważniejsze jest jak najwcześniejsze rozpoznanie etiologii zapalenia limbicznego. Nie ma szczegółowych wytycznych leczenia LE, najistotniejsze jest stosowanie leków immunosupresyjnych oraz leczenie objawowe. W przypadku LE z przeciwciałami onkoneuronalnymi leczenie polega na usunięciu i/lub leczeniu nowotworu i immunoterapii. W LE autoimmunologicznym można stosować metyloprednizolon (500-1000 mg/dobę przez $5 \mathrm{dni}$ ), immunoglobuliny (dożylnie w dawce $2 \mathrm{~g} / \mathrm{kg}$ m.c. przez $5 \mathrm{dni}$ ), plazmaferezy. W przypadku poprawy leczenie można powtarzać co 6-8 tygodni lub stosować prednizon doustnie $1 \mathrm{mg} / \mathrm{kg}$ m.c. przez kilka miesięcy (zwykle 3-6 miesięcy w pełnej dawce). Jeżeli nie uzyskuje się poprawy, zaleca się rituksimab $\left(375 \mathrm{mg} / \mathrm{m}^{2}\right)$ bądź cyklofosfamid (750 mg/m² \pm IVG 2 g/kg m.c. w 8 cyklach)] lub leczenie skojarzone. Około 60-80\% przypadków LE odpowiada w pełni na leczenie; śmiertelność jest niska, wynosi poniżej 4\%. Należy pamiętać, że LE związane z „klasycznymi” przeciwciałami onkoneuronalnymi jest złe rokowniczo, stan kliniczny poprawia się tylko $\mathrm{u}<10 \%$ pacjentów (doniesienia o lepszym rokowaniu po rituksimabie) [38]. Należy podkreślić, że leczenie przeciwpadaczkowe w LE jest zwykle nieefektywne. Napady i/lub stan padaczkowy dobrze reagują najczęściej dopiero na leczenie immunosupresyjne. Podaje się również, że leczenie tiopentalem w LE z przeciwciałami anty-NMDA może nasilać napady padaczkowe i powinno być przy takim podejrzeniu przeciwwskazane [39]. 


\section{Conflict of interest/Konflikt interesu}

Absent./Nie występuje.

\section{Financial support/Finansowanie}

Absent./Nie występuje.

\section{References/Piśmiennicłwo}

1. Brierley JB, Corsellis JA, Hierons R, Nevin S. Subacute encephalitis of later adult life mainly affecting the limbic areas. Brain 1960; 83: 357-368.

2. Nowaczyk N, Michalak S. Zaburzenia czynności poznawczych w przebiegu najczęściej występujących chorób autoimmunologicznych ośrodkowego układu nerwowego. Neuropsychiatria i Neuropsychologia 2013; 8: 101-109.

3. Thieben MJ, Lennon VA, Boeve BF, et al. Potentially reversible autoimmune limbic encephalitis with neuron al potassium channel antibody. Neurology 2004; 62: 1177-1182.

4. Gołąb-Janowska M, Nowacki P. Limbiczne zapalenie mózgu - przegląd piśmiennictwa. Roczniki PAM w Szczecinie 2011; 57: 5-11.

5. Mazurkiewicz-Bełdzińska M. Padaczka o podłożu autoimmunologicznym i zapalnym. W: Postępy w diagnostyce i leczeniu chorób układu nerwowego u dzieci. Tom 13. Jóźwiak S (ed.). Wydawnictwo Bamar; Warszawa: 2013.

6. Dalmau J, Rosenfeld M. Paraneoplastic syndromes of the CNS. Lancet Neurol 2008; 7: 327-340.

7. Dalmau J, Furneaux HM, Rosenblum MK, Graus F, Posner JB. Detection of the anti-Hu antibody in specific regions of the nervous system and tumor from patients with paraneoplastic encephalomyelitis/sensory neuronopathy. Neurology 1991; 41: 1757-1764.

8. Tüzün E, Dalmau J. Limbic encephalitis and variants: classification, diagnosis and treatment. Neurologist 2007; 13: 261-271.

9. Vincent A. Developments in autoimmune channelopathies. Autoimmun Rev 2013; 12: 678-681.

10. Bien CG, Scheffer IE. Autoantibodies and epilepsy. Epilepsia 2011; 52 (Suppl 3): 18-22.

11. Lancaster E, Dalmau J. Neuronal autoantigens-pathogenesis, associated disorders and antibody testing. Nat Rev Neurol 2012; 8: 380-390.

12. Gołąb-Janowska M, Korwin-Piotrowska T, Walecka A, Mak M, Nowacki P. Skuteczność sterydoterapii w leczeniu limbicznego zapalenia mózgu o prawdopodobnie nieparanowotworowej etiologii - opis przypadku. Aktualn Neurol 2012; 12: 176-181.

13. Wainwright MS, Martin PL, Morse RP, et al. Human herpes virus 6 limbic encephalitis after stem cell transplantation. Ann Neurol 2001; 50: 612-619.

14. Gultekin SH, Rosenfeld MR, Voltz R, et al. Paraneoplastic limbic encephalitis: neurological symptoms, immunological findings and tumor association in 50 patients. Brain 2000; 123: 1481-1494.

15. Ramanathan S, Mohammad SS, Brilot F, Dale RC. Autoimmune encephalitis: Recent updates and emerging challenges. J Clin Neurosci 2013; 21: 722-730.

16. Ances BM, Vitaliani R, Taylor RA, et al. Treatmentresponsive limbic encephalitis identified by neuropil antibodies: MRI and PET correlates. Brain 2005; 128: 1764-1777.

17. Minetti C. Autoimmune Epilepsy or exasperated search for the etiology seizures of unknown origin? Epilepsy Behav 2012; 25: 440-441.

18. Vincent A, Crino PB. Systemic and neurologic autoimmune disorders associated with seizures or epilepsy. Epilepsia 2011; 52 (Suppl 3):12-17.

19. Vincent A, Buckley C, Schott JM, et al. Potassium channel antibody-associated encephalopathy: a potentially immunotherapy-responsive form of limbic encephalitis. Brain 2004; 127: 701-712.

20. Saiz A, Blanco Y, Sabater L, et al. Spectrum of neurological syndromes associated with glutamic acid decarboxylase antibodies: diagnostic clues for this association. Brain 2008; 131: 2553-2563.

21. Kassubek J, Juengling FD, Nitzsche EU, Lucking CH. Limbic encephalitis investigated by 18FDG-PET and 3D MRI. J Neuroimaging 2001; 11: 55-59.

22. Dalmau J, Tüzün E, Wu HY, et al. Paraneoplastic anti-N-methyl-D-aspartate receptor encephalitis associated with ovarian teratoma. Ann Neurol 2007; 61: 25-36.

23. Corsellis JA, Goldberg GJ, Norton AR. "Limbic encephalitis" and its association with carcinoma. Brain 1968; 91: 481-496.

24. Zuliani L, Saiz A, Tavolato B, Giometto B, Vincent A, Graus F. Paraneoplastic limbic encephalitis associated with potassium channel antibodies: value of anti-glial nuclear antibodies in identifying the tumour. J Neurol Neurosurg Psychiatry 2007; 78: 204-205.

25. Rudzka-Dybała M, Terczyńska I, Kłyszejko J, Szczepanik E. Limbiczne zapalenie mózgu z obecnością przeciwciał anty-LGI1 u 3-letniego chłopca. Przedstawienie przypadku. Child Neurology 2014; 23: 61-66.

26. Shin YW, Lee ST, Shin JW, et al. VGKC-complex/LGI1-antybody encephalitis: clinical manifestations and response to immunotherapy. J Neuroimm 2013; 265: 75-81.

27. Lee JJ, Lee ST, Jung KH, Chu K, Lee SK. Anti-LGI1 Limbic Encephalitis Presented with Atypical Manifestations. Exp Neurobiol 2013; 22: 337-340. 
28. Lai M, Huijbers MG, Lancaster E, et al. Investigation of LGI1 as the antigen in limbic encephalitis previously attributed to potassium channels: a case series. Lancet Neurol 2010; 9: 776-785.

29. Machado S, Pinto AN, Irani SR. What should you know about limbic encephalitis? Arq Neuropsiquiatr 2012; 70: 817-822.

30. Miya K, Takahashi Y, Mori H. Anti-NMDAR autoimmune encephalitis. Brain Dev 2014; 36: 645-652.

31. Chen SJ. Immune-Mediated Limbic encephalitis. Tip of the Iceberg in Childhood Autoimmune Epilepsy. Pediatr Neonatol 2013; 54: 217-218.

32. Suleiman J, Brilot F, Lang B, et al. Autoimmune epilepsy In children: Case series and proposed guidelines for identification. Epilepsia 2013; 54: 1036-1045.

33. Zuliani L, Graus F, Giometto B, et al. Central nervous system neuronal surface antibody. Associated syndromes: review and guidelines for recognition. J Neurol Neurosurg Psychiatry 2012; 83: 638-645.

34. Bien CG, Schulze-Bonhage A, Deckert M, et al. Limbic encephalitis not associated with neoplasm as a causes of temporal lobe epilepsy. Neurology 2000; 55: 1823-1828.

35. Nowacki P. Neuropatologiczne podłoże zespołów paranowotworowych. Pol Przegl Neurol 2008; 4: 168-174.

36. Asztely F, Kumlien E. The diagnosis and treatment of limbic encephalitis. Acta Neurol Scand 2012; 126: 365-375.

37. Matà S, Muscas GC, Naldi I, et al. Non-paraneoplastic limbic encephalitis associated with anti-glutamic acid decarboxylase antibodies. J Neuroimmunol 2008; 199: 155-159.

38. Lee WJ, Lee ST, Byun JI, et al. Rituximab treatment for autoimmune limbic encephalitis in an institutional cohort. Neurology 2016; 86: 1683-1691.

39. Nair PP, Wadwekar V, Murgai A, Narayan S. Refractory status epilepticus complicated by drug-induced involuntary movements. BMJ Case Report 2014; doi:10.1136/bcr-2013-202691. 